\title{
Melatonin Concentration in Plasma, Pineal Gland and Duodenum of Pregnant Rats and their Fetuses after Melatonin and Phenytoin Administration
}

\author{
K. STEBELOVÁ ${ }^{1}$, M. MACH ${ }^{2}$, I. HERICHOVÁ ${ }^{1}$, E. UJHÁZY ${ }^{2}$, M. ZEMAN ${ }^{1}$ \\ ${ }^{1}$ Department of Animal Physiology and Ethology, Faculty of Natural Sciences, \\ Comenius University, Bratislava, Slovakia \\ ${ }^{2}$ Institute of Experimental Pharmacology, Slovak Academy of Science, Bratislava, Slovakia
}

Received November 12, 2005

Accepted April 13, 2006

\begin{abstract}
Stebelová K., M. Mach, I. Herichová, E. Ujházy, M. Zeman: Melatonin Concentration in Plasma, Pineal Gland and Duodenum of Pregnant Rats and their Fetuses after Melatonin and Phenytoin Administration. Acta Vet. Brno 2006, 75: 161-167.

Melatonin (MEL) is involved in regulation of variety of physiological processes. Beside the pineal gland, the presence of MEL was confirmed in the gastrointestinal tract (GIT), where it may exert multiple actions. We investigated the effects of a single MEL administration of 0.4, 4.0 and $40.0 \mu \mathrm{g} \mathrm{MEL} / \mathrm{ml}$ of tap water on MEL levels in rat plasma, pineal gland and duodenum. In addition, we studied the effect of a prolonged administration of MEL, an anticonvulsant drug phenytoin (PHT) and a combination of MEL+PHT, on MEL concentrations in pregnant rats and their fetuses.

Single MEL administration of 4.0 and $40.0 \mu \mathrm{g} \mathrm{MEL} / \mathrm{ml}$ resulted in a dose-related increase of MEL concentration in the rat plasma and duodenum but in a decrease of MEL in the pineal gland. After a prolonged MEL administration, MEL levels in duodenal tissues were significantly lower in control group and group treated with PHT as compared to animals, where MEL and PHT were administered simultaneously. A significant increase in MEL concentration was recorded in the intestine of fetuses taken from mothers treated with MEL and MEL + PHT. Our results indicate a dose-related absorption of MEL from tap water to GIT tissues of pregnant rats and their fetuses, where MEL may increase the protection of the intestinal mucose.
\end{abstract}

Exogenous melatonin, fetus, gastrointestinal tract, rat, phenytoin

Melatonin is a hormone discovered for the first time in the pineal gland. Its production and circulating concentration exhibits circadian rhythms with high levels seen during the night. Melatonin is considered an important internal signal entraining circadian rhythms among different organs and tissues (Cas s one 1990; Reiter 1992). This aspect of its function may account for its pleiotropic action reported at different intraorganismal levels. In addition to receptor-mediated effects, melatonin may exert its action via the antioxidative defence mechanisms (Reiter et al. 2000; Hardeland et al. 2003).

Numerous experimental studies indicate that administration of exogenous melatonin can protect against diseases caused by an excessive production of reactive oxygen species (ROS) like inflammation, neurodegenerative disorders, cancer and others (Konturek et al. 1997; Cabeza et al. 2001; Bubenik 2002). With few exceptions, circulating concentrations of MEL are usually not measured after hormone administration and MEL content in different vertebrate tissues has not been sufficiently determined (Bubenik and Pang 1997). Published data demonstrate that exogenous melatonin quickly penetrates all body organs (Messner et al. 1998) and easily crosses the placental barrier (Reppert and Klein 1978). Different tissues may selectively accumulate this hormone and increase its local concentrations (Bubenik 1980). As exogenous melatonin has been administered in a wide range of doses, it is often impossible to distinguish between physiological and pharmacological effects (Marková et al. 2003). Therefore it is important to determine what exogenous doses are required to increase circulating levels of hormone within the physiological range. 
The aim of our study was to determine the transfer of exogenous MEL into plasma and duodenum of rats after a single administration of different hormone doses, and to investigate tissue MEL concentrations after prolonged hormone administration to pregnant rats. Furthermore, we studied the transfer of melatonin into guts of fetuses after maternal administration during the entire period of pregnancy. Finally we investigated the possible interaction of melatonin with phenytoin (PHT), an anticonvulsant drug which exhibits a teratogenic effect. PHT induces embryonic hypoxia and can increase formation of ROS and free radical damage at reoxygenation (Danielss on et al. 1997).

\section{Experiment 1 \\ Materials and Methods}

Intact female Wistar rats (body weight 200-220 g) were obtained from the breeding facility Dobrá Voda, Slovak Republic and allowed to adapt to the experimental facility for 2 weeks, having free access to water and food pellets. Before and during the experiment they were exposed to constant light for 6 days to block endogenous MEL production in the pineal gland (Depres-Brummer et al. 1995) and divided into 3 experimental groups (5 animals each). MEL (Sigma, USA) was administered in drinking water for $12 \mathrm{~h}$ (from 20.00 to $8.00 \mathrm{~h}$, during their subjective night). Experimental animals were treated with $0.4,4.0$ and $40.0 \mu \mathrm{g} \mathrm{MEL} / \mathrm{ml}$ in tap water, respectively. MEL was dissolved in absolute ethanol (10 $\mathrm{mg} \mathrm{MEL} / \mathrm{ml}$ ethanol) and diluted to a final concentration with tap water. MEL is stable in water solution for at least 24 hours (Zem an et al. 1993). Control animals received the same concentration of ethanol (maximum $0.4 \%$ ) in drinking water as the experimental animals. After $12 \mathrm{~h}$ of treatment the animals were killed by decapitation (between 8:00 to 10:30 h), blood was collected and plasma stored for determination of MEL. The pineal gland and duodenum were excised and stored at $-18^{\circ} \mathrm{C}$ until MEL extraction.

\section{Experiment 2}

Pregnant Wistar rats $(n=32)$ (initial body weight 200-220 g) were kept under the light : dark regime $(12 \mathrm{~L}: 12 \mathrm{D}$; light from 6:00 to $18: 00 \mathrm{~h}$ ) to preserve synchronization during the whole experiment. Rats had free access to water and food pellets. After 2 weeks of adaptation they were divided into 4 experimental groups ( 8 animals each). The control group received ethanol in tap water at the same concentration as the experimental groups (maximum $0.4 \%$ of volume), group 2 was treated with PHT (5,5-diphenyl-2, 4-imidazolidinedione, Slovakofarma a.s., Hlohovec, Slovakia) by gavage at a dose of $150 \mathrm{mg} / \mathrm{kg}$ of body weight, group 3 was treated with MEL in tap water $(40.0 \mu \mathrm{g} / \mathrm{ml})$ and group 4 received both, PHT and MEL. MEL was administered from the beginning of pregnancy until day 19 of pregnancy to pretreat animals and increase its tissue and blood levels before PHT was given. MEL solution was available during the dark, during the light bottles contained fresh water only. Solution of MEL was prepared and exchanged daily. PHT was given between $11.00-12.00 \mathrm{~h}$ from day 7 to day 18 of pregnancy, because in previous experiment high embryonic mortality was observed up to day 5 post partum (84\%) when PHT was administered from day 2 to day 19 of pregnancy (Ujházy et al. 2000). On day 20 of pregnancy between $08.00-09.00 \mathrm{~h}$ animals were killed by decapitation and their pineal glands and duodenums were collected. Intestines of two fetuses from each litter were excised and analysed for MEL content, too.

Experiments were performed in springtime. They were carried out under an institutionally approved protocol in accordance with ethical principles and standards (Touitou et al. 2004) and were approved by the Ethical Committee at the Comenius University in Bratislava.

\section{Melatonin assay}

Samples of tissues were kept frozen $\left(-18^{\circ} \mathrm{C}\right)$ until analysis. MEL was measured by radioimmunoassay (Fras er et al. 1983) directly in plasma and after methanol and chloroform extraction in pineal glands and gut tissues, respectively. The assay was previously validated in our lab for rats (Zeman et al. 2001). Tissue samples (cca. 100 $\mathrm{mg}$ of wet tissue, fetuses - $50 \mathrm{mg}$ of wet tissue) were homogenized in $0.8 \mathrm{ml}$ of distilled water and extracted with chloroform. After centrifugation, water and lipid phases were sucked off and chloroform was evaporated under vacuum. The residues were dissolved in Tricine buffer $(0.1 \mathrm{M}, \mathrm{pH}=5.5)$. Efficiency of extraction was tested by adding 3H - MEL (2 $500 \mathrm{dpm}$ ) into each sample and was about 80\%. Sheep MEL antiserum (G/S/704-8486, Stockgrand Ltd., Guildford, UK) and 3H-labelled MEL (specific activity of 0.925-1.85 TBq/mmol; NEN Life Science Products, Bad Homburg, Germany) were used in the radioimmunoassay.

\section{Statistics}

Results are given as the arithmetic means and the standard error of means (SEM) in each animal group. Data were checked for normality and $\log 10$ transformed. The differences among groups were tested by ANOVA followed by a Tukey post-hoc test.

\section{Results}

Administration of the highest dose of MEL in tap water increased hormone concentrations in plasma $(P<0.01)$ (Fig.1A). The increase of plasma MEL concentration after a dose of 

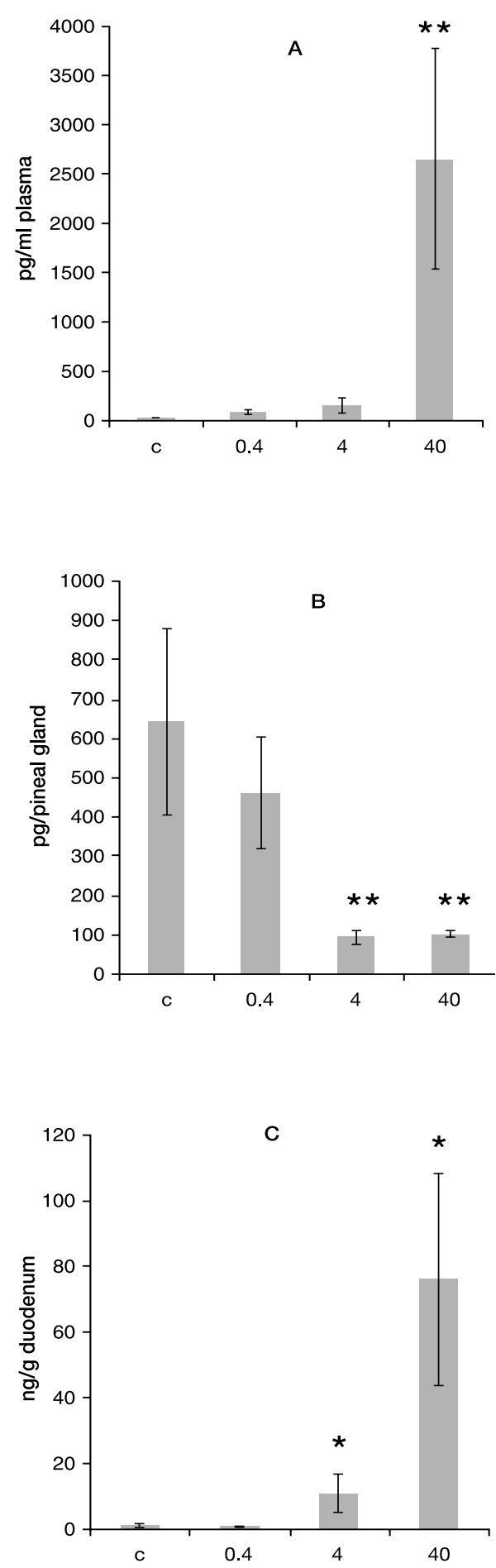

Fig. 1. Melatonin concentrations in plasma (A), pineal gland (B) and duodenum (C) of rats after single administration of melatonin ( $\mu \mathrm{g} / \mathrm{ml}$ of drinking water). Results are given as mean \pm SEM. Control group $(\mathrm{n}=$ $4)$, other groups $(n=5)$. Columns with asterisk $(*)$ are significantly different $(* P<0.05 ; * * P<0.01)$ when compared with columns without mark.

$4.0 \mu \mathrm{g} \mathrm{MEL} / \mathrm{ml}$ was close to the level of significance $(P=0.056)$. An opposite pattern was found in the pineal MEL content (Fig.1B). Treatment with exogenous MEL for 12 hours resulted in a significant decrease of pineal MEL after administration of $4 \mu \mathrm{g} \mathrm{MEL} / \mathrm{ml}$ and $40 \mu \mathrm{g} \mathrm{MEL} / \mathrm{ml}$ of tap water $(P<0.01)$. The highest MEL concentrations were detected in duodenal tissues (Fig.1C). The increase of hormone values correlated with the increasing dose of administered MEL.

A prolonged MEL (19 days) and phenytoin (PHT) (12 days) administration did not result in significant differences in the pineal MEL content (Fig. 2A). In duodenal tissues low melatonin concentrations were found in the control group and the group with added PHT (Fig. 2B). These levels were significantly lower $(P<0.001)$ in comparison with those where MEL or MEL+PHT were administered simultaneously. MEL concentrations in intestines of fetuses were significantly different among experimental groups (Fig. 3). A significant increase of the hormone level was found in fetuses, whose mothers were treated simultaneously with MEL and PHT or with MEL alone $(P<0.001)$.

\section{Discussion}

The presence of MEL has been repeatedly confirmed in the gastrointestinal tract of fishes, amphibians, reptiles, birds and mammals (Raiklin and Kvetnoy 1976; Bubenik et al. 1977; Bubenik and Pang 1997; Herichová et al. 1998; Lepage et al. 2005). Melatonin concentrations reported in the gut differ considerably among published reports. Very high MEL concentrations (4 - 100 $\mathrm{ng} / \mathrm{g}$ of tissue) were reported in duodenum 

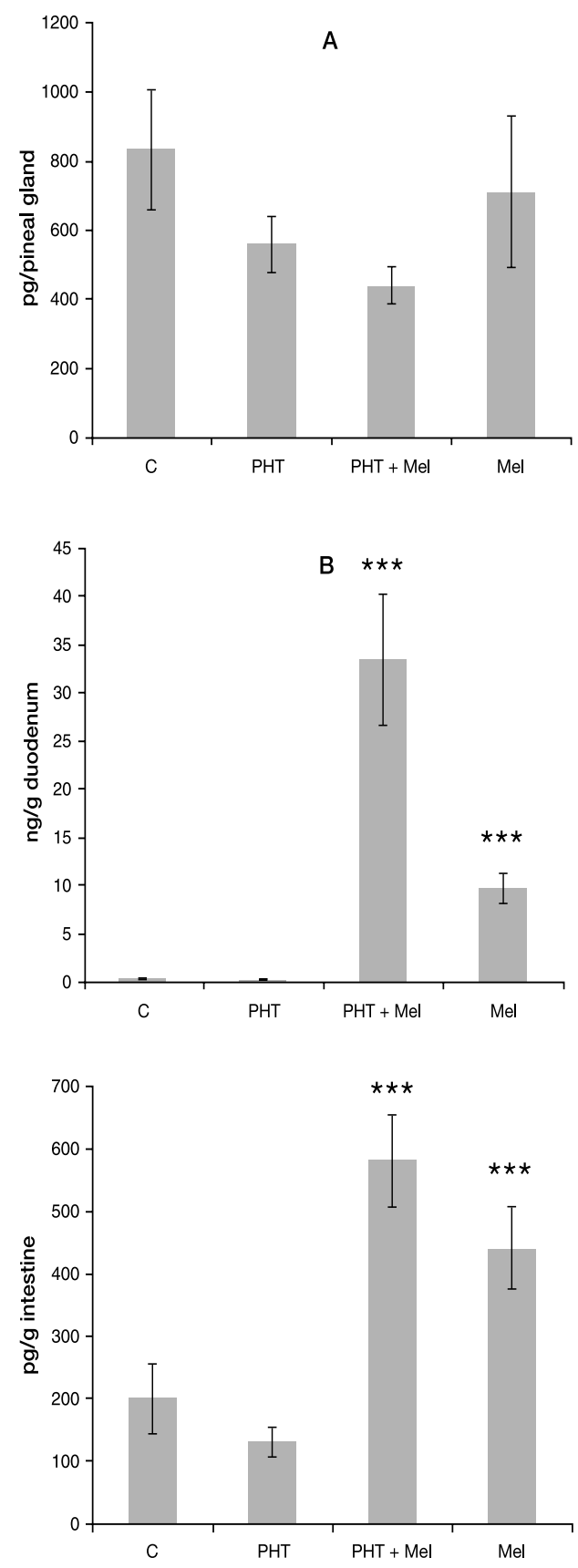

Fig. 3. Melatonin concentrations in intestine of fetuses whose mothers were given melatonin in tap water and PHT by gavage (mean \pm SEM) $(n=16)$. Columns with asterisk $(*)$ are significantly different $(* * * P<0.001)$ when compared with columns without mark.
Fig. 2. Melatonin concentrations in pineal gland (A) and duodenum (B) of pregnant rats after a prolonged administration of melatonin $(40 \mu \mathrm{g} / \mathrm{ml})$ in tap water and PHT $(150 \mathrm{mg} / \mathrm{kg})$ by gavage (mean \pm SEM) $(\mathrm{n}=$ 8). Columns with asterisk $(*)$ are significantly different $(* * * P<0.001)$ when compared with columns without mark.

of Brown Norway rats (Heuther et al. 1992), while con-siderably lower levels (200-600 pg/g of tissue) were reported by Bubenik and Brown (1997) and Zeman et al. (2001) in Wistar rats. In the present study the concentrations detected in control rats were in the range of $300-1000 \mathrm{pg} / \mathrm{g}$ of duodenal tissue.

Administration of increasing doses of MEL in drinking water during $12 \mathrm{~h}$ resulted in a dose-related increase of its levels in plasma and duodenum. High variability of circulating concentrations was observed after administration of MEL during $12 \mathrm{~h}$ and this variability may reflect the drinking pattern of rats. Volumes of consumed water were similar to those consumed during a usual $12 \mathrm{~h}$ dark period (data not shown). An individual drinking pattern was not recorded and all samples were collected 60 min after withdrawal of MEL. Since MEL is metabolised very quickly we did not administer it intragastrically but in drinking water to mimic more closely the physiological situation when melatonin is present in circulation during the dark.

The pineal MEL content was decreased after administration of two highest doses of hormone $(4.0$ and $40.0 \mu \mathrm{g} / \mathrm{ml})$ indicating that this pattern of administration resulted in a feedback effect of both doses to endogenous MEL production. Messner et al. (1998) reported a faster conversion of infused melatonin in the liver. MEL concentrations in pineal glands of control animals and rats with the lowest dose given were in a range reported in literature for the light period of a LD cycle (Binkley 1988). Our data suggest that a short-term MEL administration decreases endogenous hormone production in the pineal gland. However, prolonged (18 days) cyclic administration of MEL in drinking water 
during the dark period did not result in a lowered pineal MEL content. We hypothesize that repeated cyclic administration changes the sensitivity of the control feedback mechanisms. Following subcutaneous MEL injection a significant increase (100\%) in MEL peak amplitude in the pineal gland was observed (Both orel et al. 2002). This increase persisted over 2 days and occurred when the drug was given at the light to dark transition but not in the middle of the light or dark phase. The effect was observed also when MEL was infused directly into the suprachiasmatic nuclei (SCN) but not into the pineal gland. Data suggest that $\mathrm{SCN}$ is necessary for the effect of exogenous MEL on the amplitude of the endogenous MEL rhythm.

Increased MEL concentrations in circulation and duodenum demonstrate that MEL is effectively transferred from drinking water into the organism. A local production of MEL in the gut has been claimed (Heuther et al. 1992; Bubenik 2002) but the dose-related increase suggests that in our experiment the substantial part of intestinal MEL results from the administration of exogenous MEL. Since the molecule of MEL is highly lipophilic it should effectively cross biological membranes and distribute to all organs (MenendezPelaez and Reiter 1993).

Protective effects of MEL against ROS were demonstrated in numerous studies. High doses of exogenous MEL were shown to prevent development of gastric ulcers (Cho et al. 1989; Brzozowski et al. 1997; Melchiorri et al. 1997) and colitis (Cuzzocrea et al. 2001; Zeman et al. 2001). Several mechanisms were suggested to explain protecting effects of melatonin including an antioxidant action, restoration of microcirculation and stimulation of the immune system (Bubenik 2002). Stimulation of bicarbonate secretion is another protective mechanism mediated by MEL receptors of type MT2 localized in enterocytes (Sjoblom and Flemstrom 2004). MEL receptors were found not only in the brain and the pituitary gland but also in different peripheral organs like kidney, adrenals, intestine, heart, lungs, skin and gonads (Drew et al. 2001; Poirel et al. 2003).

PHT is known as a teratogen inducing intrauterine hypoxia with possible free radical damage after reoxygenation (Danielsson et al. 1997). Since MEL may act as a scavenger of ROS (Reiter 1995), it can protect against harmful effects induced by PHT. Moreover, MEL may be consumed in this process of scavenging of ROS by tissues and a decreased content of MEL in tissues may decrease protection against oxidative stress. However, simultaneous PHT and MEL administration did not result in depletion of MEL in the duodenum. Just the opposite, MEL content in duodenum was increased not only compared to controls but also compared to MEL alone. We suggest that PHT may decrease blood flow trough the hepatobiliary - gastrointestinal tract (Messner et al. 2001) and subsequent hypoxic state results in a decrease in MEL degradation.

Administration of MEL to pregnant female rats resulted in increased intestine hormone content of fetuses. This finding is in agreement with published data (Reppert and Klein 1978). Our results suggest that supplementation of melatonin to pregnant dams may increase an antioxidant status of progeny that is very low during the perinatal period (Gitto et al. 2001).

Numerous studies report protective effects of melatonin in many pathophysiological conditions. However, results are sometimes contradictory and this fact may reflect different given doses, since physiological concentrations may exhibit different effects than supraphysiological doses. Our study presented a range of circulating and tissue MEL concentration after exogenous MEL administration. By investigating the dose-related relationship between administered and measured hormone concentration in tissues it is possible to derive doses that induce a physiological increase of MEL in the circulation and the various tissues. 


\section{Koncentrácia melatonínu v plazme, epifýze a dvanástniku gravidných samíc potkanov a ich plodov po aplikácii melatonínu a fenytoínu}

Melatonín (MEL) je zapojený do regulácie rôznych fyziologických procesov. Okrem epifýzy bola prítomnost MEL potvrdená aj v gastrointestinálnom trakte, kde môže mat' regulačné a protektívne funkcie. Za účelom zistenia prieniku MEL do tkanív vo fyziologických koncentráciách sme študovali vplyv jeho jednorazovej aplikácie. Hormón sme podávali v dávke $0,4,4,0$ a 40,0 $\mu \mathrm{g} \mathrm{MEL} / \mathrm{ml}$ pitnej vody a sledovali hladiny MEL v plazme, epifýze a dvanástniku potkana. Následne sme sledovali vplyv prolongovaného podávania MEL v dávke 40,0 $\mu \mathrm{g} \mathrm{MEL} / \mathrm{ml}$, antiepileptika fenytoínu (PHT) a kombinácie podávania MEL+PHT na koncentrácie MEL u gravidných samíc potkanov a ich plodov.

Jednorazová aplikácia MEL v dávke 4,0 a 40,0 $\mu \mathrm{g}$ MEL/ml vyvolala od dávky závislý vzostup MEL v plazme a dvanástniku potkanov, ale pokles koncentrácie MEL v epifýze. Po prolongovanom podávaní MEL boli hladiny MEL v dvanástniku signifikantne nižšie u kontrolnej skupiny a skupiny, ktorej bol podávaný PHT v porovnaní so zvieratami, u ktorých MEL a PHT bol podávaný súčasne. Signifikantný vzostup v koncentrácii MEL bol zistený aj v tkanive čreva plodov od samíc, ktorým bol podávaný MEL a MEL+PHT. Naše výsledky poukazujú na dávkovo závislú absorpciu MEL podávaného $\mathrm{v}$ pitnej vode do tkaniva dvanástnika gravidných samíc aj ich plodov, kde MEL môže zvyšovat ochranu črevnej mukózy.

\section{Acknowledgement}

Research was supported by grants VEGA No 1/1294/04, No 2/5052/25 and APVT-20-022704.

\section{References}

BINKLEY S 1988: The pineal. Prentice Hall, Englewood Cliffs, New York, 304 p.

BOTHOREL B, BARASSIN S, SABOUREAU M, PERREAU S, VIVIEN-ROELS B, MALAN A, PEVET P 2002: In the rat, exogenous melatonin increases the amplitude of pineal melatonin secretion by a direct action on the circadian clock. Eur J Neurosci 16: 1090-1098

BRZOZOWSKI T, KONTURE, PC, KONTUREK SJ, PAJDO R, BIELANSKI W, BRZOZOWSKA I, STACHURA J, HAHN EG 1997: The role of melatonin and L-tryptophan in prevention of acute gastric lesions induced by stress, ethanol, ischemia, and aspirin. J Pineal Res 23: 79-89

BUBENIK GA 1980: Localization of melatonin in the digestive tract of the rat. Effect of maturation, diurnal variation, melatonin treatment and pinealectomy. Horm Res 12: 313-323

BUBENIK GA 2002: Gastrointestinal melatonin: localization, function, and clinical relevance. Dig Dis Sci 47: 2336-2348

BUBENIK GA, BROWN GM 1997: Pinealectomy reduces melatonin levels in the serum but not in the gastrointestinal tract of rats. Biol Signals 6: 40-44

BUBENIK GA, BROWN GM, GROTA LJ 1977: Immunohistological localization of melatonin in the rat digestive system. Experientia 33: 662-663

BUBENIK GA, PANG SF 1997: Melatonin levels in the gastrointestinal tissues of fish, amphibians, and a reptile. Gen Comp Endocrinol 106: 415-419

CABEZA J, MOTILVA V, MARTIN MJ, DE LA LASTRA CA 2001: Mechanisms involved in gastric protection of melatonin against oxidant stress by ischemia-reperfusion in rats. Life Sci 68: 1405-1415

CASSONE VM 1990: Effects of melatonin on vertebrate circadian systems. Trends Neurosci 13: 457-464

CUZZOCREA S, MAZZON E, SERRAINO I, LEPORE V, TERRANOVA ML, CICCOLO A, CAPUTI AP 2001: Melatonin reduces dinitrobenzene sulfonic acid-induced colitis. J Pineal Res 30: 1-12

DANIELSSON BR, AZARBAYJANI F, SKOLD AC, WEBSTER WS 1997: Initiation of phenytoin teratogenesis: pharmacologically induced embryonic bradycardia and arrhythmia resulting in hypoxia and possible free radical damage at reoxygenation. Teratology 56: 271-281

DEPRES-BRUMMER P, LEVI F, METZGER G, TOUITOU Y 1995: Light-induced suppression of the rat circadian system. Am J Physiol 268: R1111-1116

DREW JE, BARRETT P, MERCER JG, MOAR KM, CANET E, DELAGRANGE P, MORGAN PJ 2001: Localization of the melatonin-related receptor in the rodent brain and peripheral tissues. J Neuroendocrinol 13: 453-458

FRASER S, COWEN P, FRANKLIN M, FRANEY C, ARENDT J 1983: Direct radioimmunoassay for melatonin in plasma. Clin Chem 29: 396-397

GITTO E, KARBOWNIK M, REITER RJ, TAN DX, CUZZOCREA S, CHIURAZZI,P, CORDARO S, CORONA G, TRIMARCHI G, BARBERI I 2001: Effects of melatonin treatment in septic newborns. Pediatr Res 50: 756-760 
HARDELAND R, COTO-MONTES A, POEGGELER B 2003: Circadian rhythms, oxidative stress, and antioxidative defense mechanisms. Chronobiol Int 20: 921-962

HERICHOVÁ I, ZEMAN M, VESELOVSKÝ J 1998: Effect of tryptophan administration on melatonin concentrations in the pineal gland, plasma and gastrointestinal tract of chickens. Acta vet Brno 67: 89-95

HUETHER G, POEGGELER B, REIMER A, GEORGE A 1992: Effect of tryptophan administration on circulating melatonin levels in chicks and rats: evidence for stimulation of melatonin synthesis and release in the gastrointestinal tract. Life Sci 51: 945-953

CHO CH, PANG SF, CHEN BW, PFEIFFER CJ 1989: Modulating action of melatonin on serotonin-induced aggravation of ethanol ulceration and changes of mucosal blood flow in rat stomachs. J Pineal Res 6: 89-97

KONTUREK PC, KONTUREK SJ, BRZOZOWSKI T, DEMBINSKI A, ZEMBALA M, MYTAR B, HAHN EG 1997: Gastroprotective activity of melatonin and its precursor, L-tryptophan, against stress-induced and ischaemia-induced lesions is mediated by scavenge of oxygen radicals. Scand J Gastroenterol 32: 433-438

LEPAGE O, LARSON ET, MAYER I, WINBERG S 2005: Tryptophan affects both gastrointestinal melatonin production and interrenal activity in stressed and nonstressed rainbow trout. J Pineal Res. 38: 264-271

MARKOVÁ M, ADAMEKOVÁ E, KUBATKA P, BOJKOVÁ B, AHLERSOVÁ E, AHLERS I 2003: Effect of prolonged melatonin administration on metabolic parameters and organ weights in young male and female Sprague-Dawley rats. Acta vet Brno 72: 163-173

MELCHIORRI D, SEWERYNEK E, REITER RJ, ORTIZ GG, POEGGELER B, NISTICO G 1997: Suppressive effect of melatonin administration on ethanol-induced gastroduodenal injury in rats in vivo. Br J Pharmacol 121: 264-270

MENENDEZ-PELAEZ A, REITER RJ 1993: Distribution of melatonin in mammalian tissues: the relative importance of nuclear versus cytosolic localization. J Pineal Res 15: 59-69

MESSNER M, HARDELAND R, RODENBECK A, HUETHER G 1998: Tissue retention and subcellular distribution of continuously infused melatonin in rats under near physiological conditions. J Pineal Res 25: 251-259

MESSNER M, HUETHER G, LORF T, RAMADORI G, SCHWÖRER H 2001: Presence of melatonin in the human hepatobiliary-gastrointestinal tract. Life Sciences 69: 543-551

PENTNEY PT, BUBENIK GA 1995: Melatonin reduces the severity of dextran-induced colitis in mice. J Pineal Res 19: 31-39

POIREL VJ, CAILOTTO C, STREICHER D, PEVET P, MASSON-PEVE, M, GAUER F 2003: MT1 melatonin receptor mRNA tissular localization by PCR amplification. Neuro Endocrinol Lett $24: 33-38$

RAIKHLIN NT, KVETNOY IM 1976: Melatonin and enterochromaffine cells. Acta Histochem 55: 19-24

REITER RJ 1992: The ageing pineal gland and its physiological consequences. Bioessays 14: 169-175

REITER RJ 1995: Functional pleiotropy of the neurohormone melatonin: antioxidant protection and neuroendocrine regulation. Front Neuroendocrinol 16: 383-415

REITER RJ, TAN DX, OSUNA C, GITTO E 2000: Actions of melatonin in the reduction of oxidative stress. J Biomed Sci 7: 444-458

REPPERT SM, KLEIN DC 1978: Transport of maternal [3H] melatonin to suckling rats and the fate of [3H] melatonin in the neonatal rat. Endocrinology 102: 582-588

SJOBLOM M, FLEMSTROM G 2004: Central nervous alpha1-adrenoceptor stimulation induces duodenal luminal release of melatonin. J Pineal Res 36: 103-108

TOUITOU Y, PORTALUPPI F, SMOLENSKY MH, RENSING L 2004: Ethical principles and standards for the conduct of human and animal biological rhythm research. Chronobiol Int 21: 161-170

UJHÁZY E, DUBOVICKÝ M, MACH M, JURÁNEK I, NAVAROVÁ J, SADLOŇOVÁ I, GAJDOŠÍK A 2000: Effect of phenytoin on prenatal and postnatal development of rats. Biologia Suppl 8: 125-130

ZEMAN M, NOSALOVÁ V, BOBEK P, ZAKALOVÁ M, ČERNÁ S 2001: Changes of endogenous melatonin and protective effect of diet containing pleuran and extract of black elder in colonic inflammation in rats. Biologia 56: 695-701

ZEMAN M, VÝBOH P, JURÁNI M, LAMOŠOVÁ D, KOŠŤÁL L, BILČÍK B, BLAŽÍČEK P, JURÁNIOVÁ E 1993: Effects of exogenous melatonin on some endocrine, behavioural and metabolic parameters in Japanese quail Coturnix coturnix japonica. Comp Biochem Physiol Comp Physiol 105: 323-328 